\title{
Natural Resistance to Clover yellow vein virus in Beans Controlled by a Single Recessive Locus
}

\author{
Masanao Sato, ${ }^{1}$ Chikara Masuta, ${ }^{2}$ and Ichiro Uyeda ${ }^{1}$ \\ ${ }^{1}$ Pathogen-Plant Interactions and ${ }^{2} \mathrm{C}$ ell Biology and Manipulation Groups, Graduate School of Agriculture, Hokkaido \\ University, Sapporo 060-8589, Japan.
}

Submitted 3 February 2003. Accepted 24 June 2003.

\begin{abstract}
We characterized the resistance of the common bean cv. Jolanda to Clover yellow vein virus no. 30 (CIYVV). After inoculation, the virus was detected in neither inoculated nor upper leaves, suggesting that the resistance operates at either the viral replication or cell-to-cell movement level. To analyze the mechanism of resistance, we developed a green fluorescent protein (GFP)-tagged CIYVV, and monitored GFP fluorescence at sites of infection on CIYVV-inoculated leaves. No GFP fluorescence was detected in Jolanda, whereas its expression in single cells and spread on inoculated leaves were observed clearly in susceptible cultivars. CIYVV-introduced Jolanda cells were found to be still viable; therefore, it is unlikely that the restriction of multiplication was due to rapid cell death. Genetic analysis indicated that a single recessive locus controlled the resistant phenotype of Jolanda. We designated this locus desc (determinant of susceptibility to CIYVV). Meanwhile, a spontaneous mutant virus that overcomes the resistance (CIYVV-Br) was isolated. Inoculation assays using chimeric viruses suggested that a viral genome-linked protein (VPg) might be the avirulence determinant. The resistance mechanism may be associated with the role of VPg in the viral infection cycle.
\end{abstract}

Additional keywords: particle bombardment, Phaseolus vulgaris, potyvirus.

Clover yellow vein virus no. 30 (ClYVV) belongs to the genus Potyvirus, which includes a large number of plant viruses. This virus was formerly classified as Bean yellow mosaic virus (BYMV), but was subsequently identified as a member of ClYVV (Uyeda et al. 1975, 1991). Potyviruses often cause severe damage to important crops (Shukla et al. 1994); therefore, natural resistance has been investigated for breeding programs (Provvidenti and Hampton 1992). Approximately 40\% of the known resistance loci to potyviruses are recessive. Recessive resistance is often strain or pathotype specific (Johansen et al. 2001; Keller et al. 1998; Masuta et al. 1999; Nicolas et al. 1996; Schaad et al. 1997b), and may be explained by the lack of a host factor or factors essential for viral infection. Past studies have found some molecular evidence for recessive resistance in the virus host. For example, a viral genome-linked protein (VPg) has been identified as an avirulence determinant in several cases (Hjulsager et al. 2002; Keller et al. 1998; Masuta et al. 1999; Nicolas et al. 1997; Ramajaki and Valkonen 2002; Schaad et al. 1997b). Another determinant is the cistron covering the P3-6k1 region (Johansen et al. 2001). In addition to viral factors, knowl-

Corresponding author: I. Uyeda, E-mail: uyeda@res.agr.hokudai.ac.jp; Fax: +81 117062483 edge of host factors involved in recessive resistance has accumulated. The recessive gene $v a$ in tobacco, which confers resistance to several potyviruses, such as Potato virus $Y$ (PVY) and Tobacco vein mottling virus, is associated with a large chromosomal deletion (Noguchi et al. 1999), indicating that lack of some gene or genes in the deleted region confers resistance. Recently, one such host factor, eIF(iso)4E, was identified in analyses of ethyl methanesulfonate-mutagenized Arabidopsis thaliana showing loss of susceptibility to the potyviruses Turnip mosaic virus (TuMV) and Tobacco etch virus (TEV) (Lellis et al. 2002). When the gene for eIF(iso)4E was disrupted by T-DNA insertion in transgenic A. thaliana, the plants lost susceptibility to TuMV and Lettuce mosaic virus (LMV), but not to Cucumber mosaic virus (CMV) (Duprat et al. 2002). To obtain a better understanding of such recessive resistance to potyviruses, we analyzed a newly identified recessive gene that confers resistance to CIYVV in the common bean cv. Jolanda. The locus was designated desc (determinant of susceptibility to ClYVV), and was compared with the recessive genes reported for resistance to Bean common mosaic virus (BCMV), another legume-infecting potyvirus.

To follow viral infectivity in living cells, we successfully integrated a reporter gene green fluorescent protein (GFP) into the ClYVV genome (Masuta et al. 2000). In this study, we describe the nature of the resistance gene desc and CIYVV using GFP-tagged ClYVV.

\section{RESULTS}

Screening CIYVV-resistant common bean cultivars.

Sixteen cultivars, previously selected for resistance to BYMV, were tested for resistance to CIYVV. Inocula were prepared from upper leaves of broad bean plants inoculated with cloned ClYVV (pClYVV; Fig. 1) (Takahashi et al. 1997). In all, 5 to 10 plants of each cultivar were inoculated with the virus. Of 16 cultivars, 12 showed leaf distortion and vein clearing in upper leaves within 10 days postinoculation (dpi). Then, all the plants were subjected to enzyme-linked immunosorbent assay (ELISA) to confirm virus infection. No virus was detected in inoculated or upper leaves of Jolanda using ELISA (Table 1). Symptoms were not observed in Jolanda, Chuiku F15gou (CF-15), Chuko 9402, or Great Northern 131, although ELISA detected the virus in a few plants of those cultivars, except for Jolanda. We found a spontaneous mutant in the infected CF-15, as described below.

In addition to ELISA, a bioassay was conducted to ensure that ClYVV cannot infect Jolanda. Symptoms and virus infection were not observed in a susceptible cultivar, Taishokintoki, when the inoculated leaves of Jolanda were used as an inoculum, indicating that Jolanda inhibits CIYVV infection in inoculated leaves. 


\section{Monitoring viral infection by GFP-tagged CIYVV.}

Previously, we developed a ClYVV vector (Masuta et al. 2000) that expresses GFP (cycle 3 mutant) (Crameri et al. 1996). In the present study, to better monitor the spread of the virus in living cells, cycle3 was replaced with GFP-S65T (Davis and Vierstra 1998), generating another CIYVV-GFP

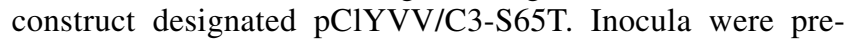
pared from upper leaves of broad bean plants inoculated with pCIYVV/C3-S65T. The GFP-tagged virus spread systemically in susceptible common bean cultivars. Accumulation of the GFP-tagged virus in the systemically infected leaves was slightly reduced compared with the parental virus (Fig. 2). There was no difference in the development of symptoms between the parental and recombinant viruses. When Jolanda was inoculated with the GFP-tagged virus, no virus was detected in the inoculated or upper leaves using ELISA.

After inoculating leaves of the susceptible cv. Taishokintoki with ClYVV/C3-S65T, GFP fluorescence was first observed in single cells $20 \mathrm{~h}$ postinoculation (hpi) (Fig. 3A) and it then spread to the surrounding cells (Fig. 3B). At 3 to $5 \mathrm{dpi}$, GFP fluorescence was observed in cells distant from the initial sites of infection (Fig. 3C). Conversely, no fluorescence was detected in the inoculated Jolanda leaves, even 5 dpi (Fig. 3D).
Table 1. Inoculation of ClYVV onto bean cultivars ${ }^{\mathrm{a}}$

\begin{tabular}{lcc}
\hline Cultivars & Symptoms $^{\mathbf{b}}$ & ELISA $^{\mathbf{c}}$ \\
\hline BO19 & + & + \\
Chuiku F15gou & - & \pm \\
Chuko 9401 & + & + \\
Chuko 9402 & - & \pm \\
Chuko 9404 & + & + \\
Fukutoramame & + & + \\
Great Northern & + & + \\
Great Northern 131 & - & + \\
Great Northern Beans 21073 & + & + \\
Great Northern Beans 21079 & + & + \\
Great Northern Line & + & + \\
Great Northern U 159 & + & + \\
Great Northern Ui 123 & + & + \\
Jolanda & - & + \\
Taishokintoki & + & + \\
Toyaofuku & + & + \\
\hline
\end{tabular}

${ }^{a}$ Five to ten plants in each cultivar were subjected to inoculation. Consistently in three independent experiments, Jolanda did not show any symptoms and virus infection was obtained.

${ }^{\mathrm{b}}$ Symptom were observed on upper leaves at 10 days postinoculation. + = symptoms such as vein clearing, leaf distortion, and stunting; $-=$ no symptoms.

c. $\pm=$ consistent results were not obtained.

pervv

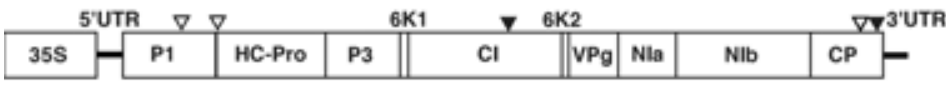

pCIrVV/C3-S65T

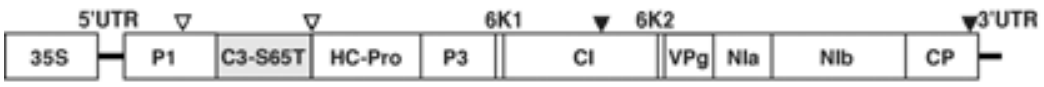

PE2113-ECFP

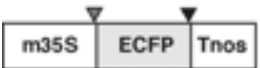

Fig. 1. Schematic representations of the constructs used in this study. pClYVV was first constructed by Takahashi and associates (1997), and pClYVV/C3S65T was constructed from green fluorescent protein-tagged CIYVV (Masuta et al. 2000). m35S = modified 35S promoter (Mitsuhara et al. 1996); ECFP = enhanced cyan fluorescent protein. White, gray, and black triangles indicate PstI, BamHI, and SacI sites, respectively.
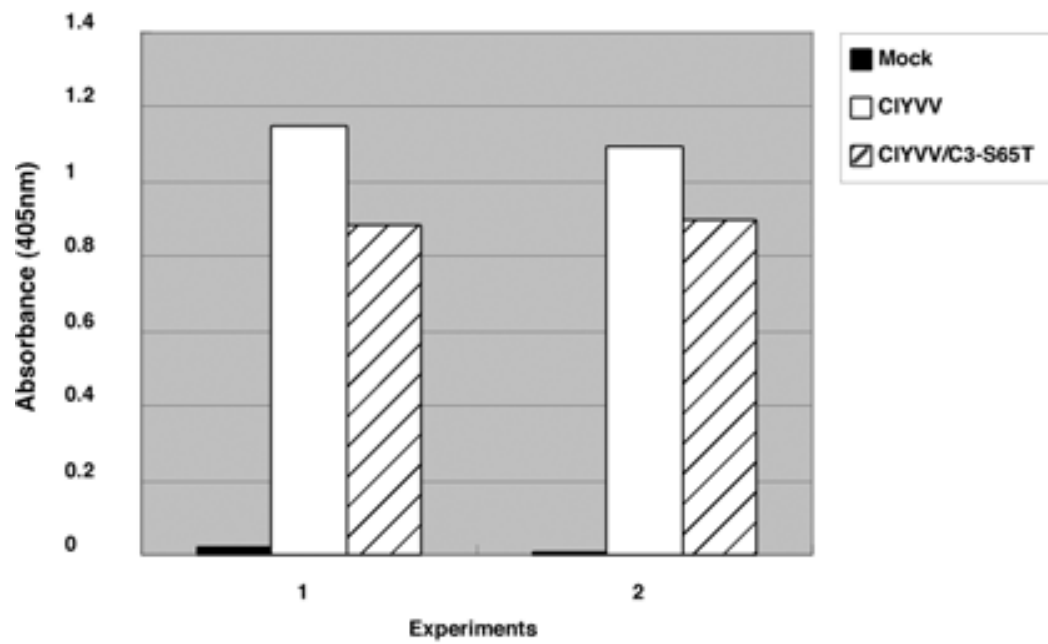

Fig. 2. Accumulation of ClYVV in the systemically infected leaves of common bean cultivar Taishokintoki. The viral concentrations were estimated using conventional enzyme-linked immunosorbent assay. 


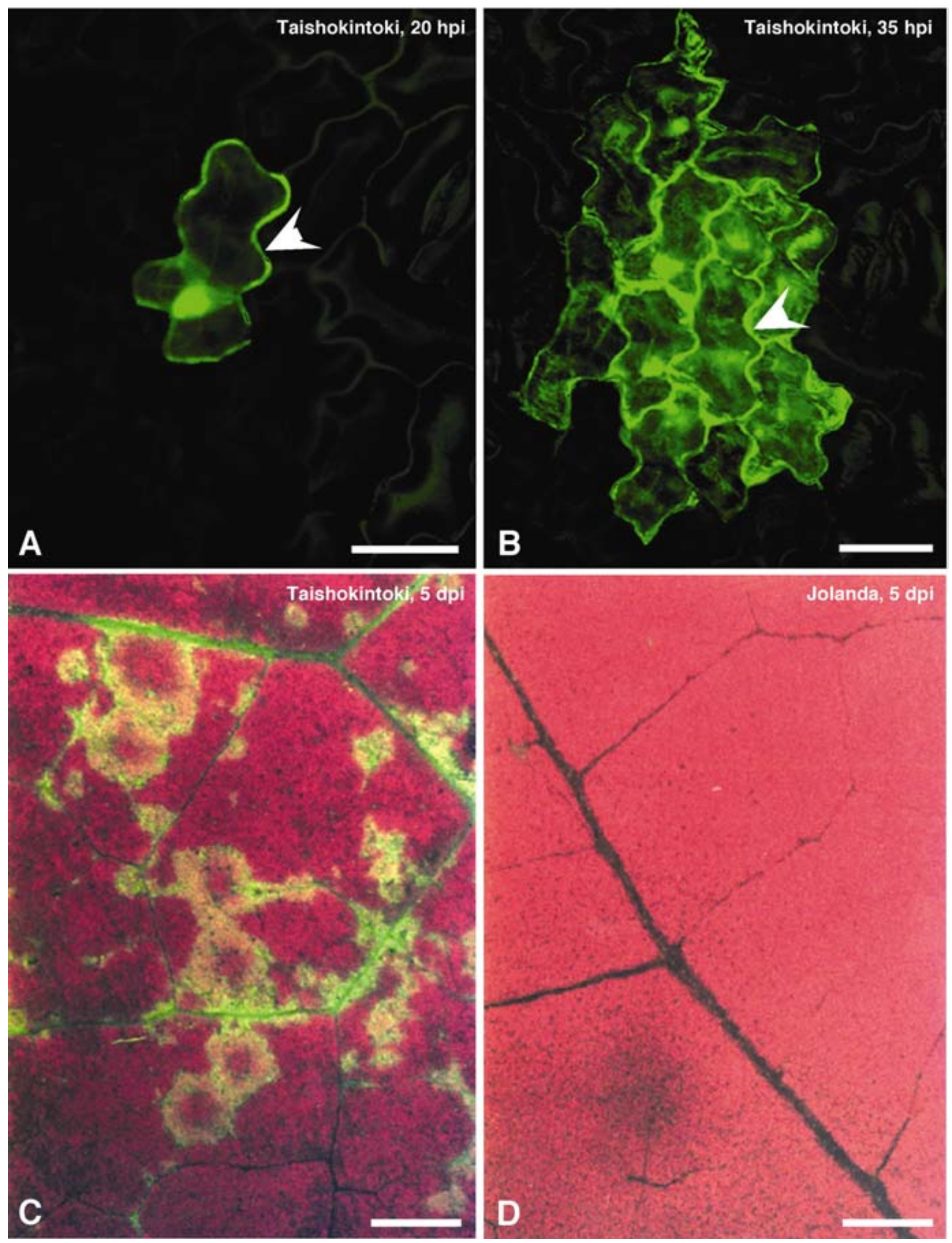

Fig. 3. Monitoring ClYVV/C3-S65T infection on the leaves of common bean cultivars. A and B, Confocal microscopic images of ClYVV/C3-S65T infection in Taishokintoki. Green fluorescent protein (GFP) was first detected in a single cell $20 \mathrm{~h}$ postinoculation (hpi) (A) and then spread to the surrounding cells (B). The image in B was taken 35 hpi. Arrowheads indicate an initially infected cell. Scale bar $=250 \mu \mathrm{m}$. C and D, Epifluorescence microscopic images of ClYVV/C3-S65T 5 days postinoculation (dpi). The virus spread through veins of Taishokintoki (C), while no GFP fluorescence was observed even 5 dpi (D). Scale bar $=2 \mathrm{~mm}$. 
Inhibition of CIYVV infection analyzed using biolistic assays.

To introduce ClYVV/C3-S65T into Jolanda cells, we used particle bombardment. pClYVV and pClYVV/C3-S65T did not establish detectable infection in either inoculated or upper leaves of Jolanda (data not shown). The absence of detectable GFP fluorescence in CIYVV/C3S65T-inoculated Jolanda might have been due to either the inhibition of infection at single cells or a micro-hypersensitive reaction (HR), which induces smaller lesions rather than typical, visible lesions (Cooley et al. 2000). To determine whether cell death in initially infected cells occurred and affected reporter gene expression in Jolanda, we constructed pCl-35:G:N (Fig. 4A). The plasmid carrying
Table 2. Numbers of cells that show green fluorescent protein (GFP)

\begin{tabular}{lccccc}
\hline & \multicolumn{2}{c}{ Taishokintoki } & & \multicolumn{2}{c}{ Jolanda } \\
\cline { 2 - 3 } \cline { 5 - 6 } Plasmid $^{\mathbf{a}}$ & $\mathbf{1 2}^{\mathbf{b}}$ & $\mathbf{2 4}$ & & $\mathbf{1 2}$ & $\mathbf{2 4}$ \\
\hline $\begin{array}{l}\text { pCl-35:G:N (GFP } \\
\text { with ClYVV) }\end{array}$ & $158.5 \pm 1.5^{\mathrm{c}}$ & $253.0 \pm 21.0$ & & $167.5 \pm 5.5$ & $224.0 \pm 18.0$ \\
$\begin{array}{l}\text { psmRSGFP (GFP } \\
\text { without ClYVV) }\end{array}$ & $77.0 \pm 8.0$ & $97.0 \pm 7.0$ & & $74.0 \pm 4.0$ & $87.5 \pm 5.5$
\end{tabular}

a DNA was introduced into epidermal cells by particle bombardment.

b Hours postbombardment.

${ }^{\mathrm{c}}$ Mean value ( \pm standard deviation) calculated from six samples for each treatment.

A

$\mathrm{pCl}-35: \mathrm{G}: \mathrm{N}$

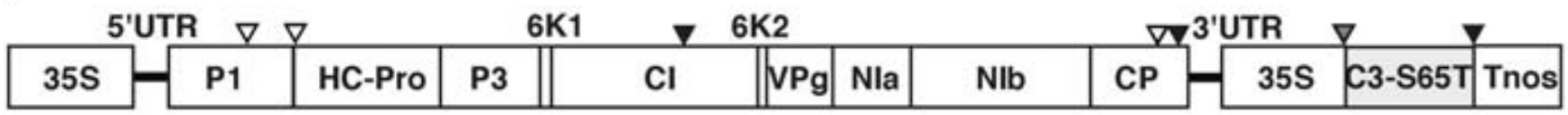

\section{psmRSGFP}

\begin{tabular}{|l|l|l|}
\hline $35 S$ & C3-S65T & Tnos \\
\hline
\end{tabular}

B

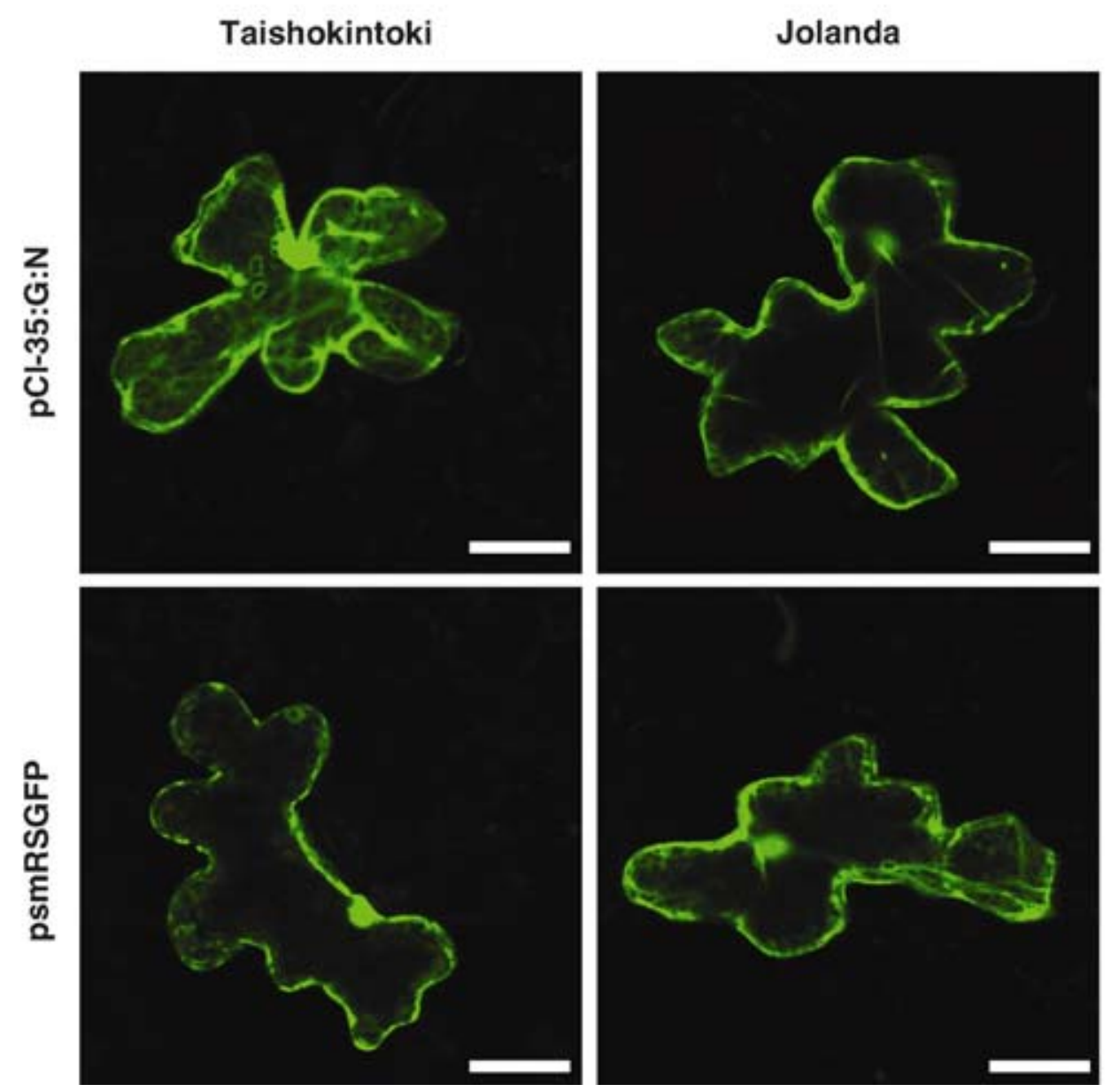

Fig. 4. Green fluorescent protein (GFP) expression in the cells cointroduced with ClYVV on leaves of susceptible and resistant cultivars. A, Constructs used to achieve separate expression of GFP from pClYVV. White, gray, and black triangles indicate PstI, BamHI, and SacI sites, respectively. B, GFP expression observed by confocal laser microscopy $24 \mathrm{~h}$ after bombardment. Scale bar $=130 \mu \mathrm{m}$. 
only GFP downstream from 35S promoter (psmRSGFP) was used as a control for cell viability. Three to four leaves for each construct were used in three independent experiments. The numbers of cells showing GFP fluorescence were counted 12 and $24 \mathrm{~h}$ after bombardment with these plasmids (Fig. 4B; Table 2). The data were analyzed using 1-way analysis of variance. A significant increase in the number of GFP-expressing cells was observed between the two observation times (12 and $24 \mathrm{~h}$ after introduction) regardless of cultivar (Jolanda or Taishokintoki) or treatment (GFP or GFP + ClYVV). The statistical analyses resulted in the values $F=28.6, \mathrm{df}=1, P<0.01$ for Jolanda treated with GFP; $F=73.7, \mathrm{df}=1, P<0.01$ for Jolanda treated with GFP + ClYVV; $F=29.6$, df $=1, P<0.01$ for Taishokintoki treated with GFP; and $F=75.6$, df $=1, P<0.01$ for Taishokintoki treated with GFP + ClYVV. We also found a clear increase in the intensity of fluorescence over time, indicating that GFP expression was not affected by the mechanism of resistance.
That is, cells were viable when the plasmid carrying the virus was introduced.

To confirm that no GFP fluorescence was expressed from pClYVV/C3-S65T in Jolanda after its introduction, we co-introduced pClYVV/C3-S65T with pE2113-ECFP (Fig. 1), which contains the enhanced cyan fluorescent protein (ECFP) gene under the control of a modified 35S promoter (Mitsuhara et al. 1996). In the leaves of Taishokintoki, GFP fluorescence spread from the cells expressing ECFP fluorescence (Fig. 5A and B), whereas no GFP fluorescence was detected in the Jolanda cells expressing ECFP (Fig. 5C and D). We counted the number of cells expressing ECFP and GFP in two or three leaves in three independent experiments (Table 3). Simultaneous expression of GFP and ECFP was observed in 20 to $30 \%$ of the Taishokintoki cells. By contrast, no cells expressing GFP were seen in Jolanda, although ECFP fluorescence was detected with almost the same introduction efficiency as that of
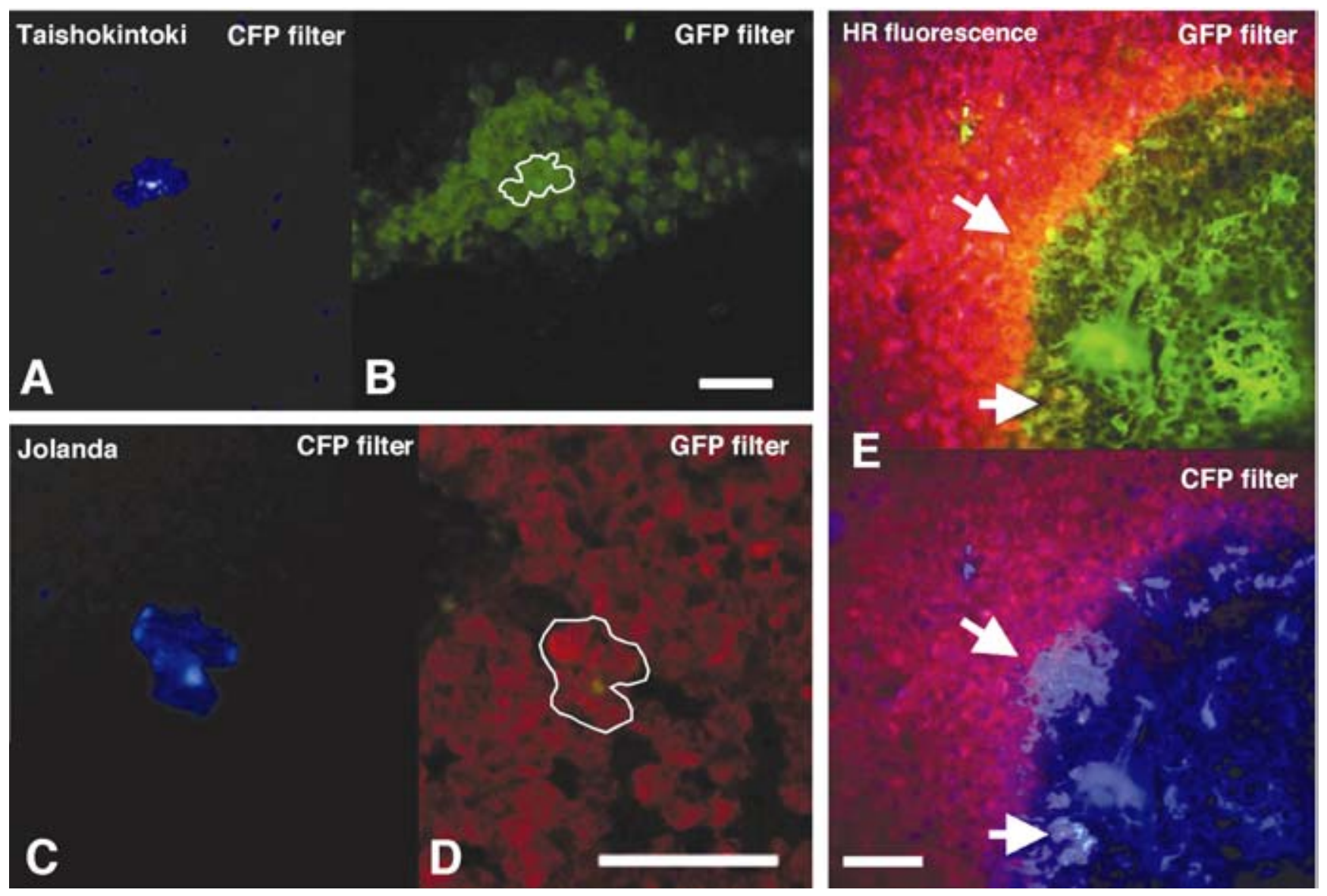

Fig. 5. Cointroduction of enhanced cyan fluorescent protein and CIYVV/C3-S65T into A and $\mathbf{B}$, susceptible and $\mathbf{C}$ and $\mathbf{D}$, resistant cultivars by particle bombardment. Images in A and C were obtained using the filter for cyan fluorescent protein (CFP), while those in B and D were obtained using the filter for green fluorescent protein (GFP). All images were taken under an epifluorescence microscope. Scale bar $=160 \mu \mathrm{m}$. E, Dead or dying cells in or around a local lesion of Taishokintoki inoculated with Cucumber mosaic virus were also examined as a negative control to allow GFP fluorescence to be distinguished from autofluorescence caused by hypersensitive reaction (C. Masuta, unpublished data). Arrows indicate strong fluorescence from the representative cells in a local lesion. Note that this autofluorescence did not differ with the GFP and CFP filters. Scale bar $=70 \mu \mathrm{m}$.

Table 3. Number of cells expressing green fluorescent protein (GFP) and enhanced cyan fluorescent protein (ECFP) ${ }^{\mathrm{a}}$

\begin{tabular}{|c|c|c|c|c|c|}
\hline \multicolumn{3}{|c|}{ Taishokintoki $^{\text {b }}$} & \multicolumn{3}{|c|}{ Jolanda $^{\text {b }}$} \\
\hline GFP & ECFP & GFP + ECFPc & GFP & ECFP & GFP + ECFP \\
\hline 13 & 40 & 8 & 0 & 37 & 0 \\
\hline 15 & 37 & 8 & 0 & 42 & 0 \\
\hline 17 & 45 & 13 & 0 & 38 & 0 \\
\hline
\end{tabular}

${ }^{a}$ GFP and ECFP are expressed from pCIYVV/C3-S65T and pE2113-ECFP, respectively.

${ }^{\mathrm{b}}$ Taishokintoki is a CIYVV-susceptible cultivar, while Jolanda is resistant.

${ }^{c} 0.5 \mathrm{mg}$ of DNA was introduced into epidermal cells in primary leaves in each experiment. 
Taishokintoki, indicating specific inhibition of GFP-tagged virus infection in this cultivar. To test whether we were observing autofluorescence induced by HR (cell death), we inoculated CMV Y strain onto Taishokintoki, which resulted in local lesions due to HR (C. Masuta, unpublished data). If cells die due to HR, the resultant autofluorescence cannot be discriminated by the CFP and GFP filters. The autofluorescence of representative cells in or around a local lesion is shown in Figure 5E. Strong fluorescence in a local lesion was observed through both GFP and CFP filters. Therefore, we believe that the introduction of ClYVV into Jolanda did not trigger cell death.

\section{Existence of a single, recessive CIYVV resistance gene.}

To understand the mode of inheritance of resistance, we performed genetic analyses of crosses between the two cultivars (Taishokintoki and Jolanda). Using the GFP-monitoring system described above, it took only a few days to determine resistance after inoculation of ClYVV/C3-S65T onto detached leaves. All of the $F_{1}$ plants from the reciprocal combination of crossing showed the susceptible phenotype, indicating that the resistant trait was recessive (Table 4). The $\mathrm{F}_{2}$ plants showed a susceptible:resistant segregation ratio of nearly $3: 1$. The $\chi^{2}$ and $P$ values shown in Table 4 supported the control of resistance by a single recessive gene. Furthermore, the $F_{1}$ plants backcrossed to Jolanda showed a susceptible:resistant segregation ratio of 1:1. The $F_{2}$ plants that showed resistance were allowed to self to obtain $\mathrm{F}_{3}$ populations. Their phenotype did not segregate, and all the plants showed resistance. These observations suggest that the CIYVV resistance of Jolanda is controlled by a nuclear-encoded recessive gene; we designated this resistant allele desc.
Comparison of desc and known BCMV resistance genes.

Jolanda has been shown to contain loci $(I, b c-1-1$, and $b c-u)$ that confer resistance to BCMV (Drijfhout 1978); therefore, we examined the possibility that desc was actually one of these BCMV resistance loci. We collected 11 cultivars harboring BCMV resistance genes, and classified them into three groups (A to $\mathrm{C}$ ) depending on the BCMV resistance genes carried (Table 5). Of the 11 cultivars, 9 were found to be susceptible to ClYVV, regardless of class. These susceptible cultivars showed symptoms and GFP fluorescence in upper leaves within 10 dpi. This suggests that the three BCMV resistance genes are not associated with CIYVV resistance. The two cultivars that showed resistance to ClYVV, Evolutie and Imuna, were analyzed further. These cultivars were crossed with either Taishokintoki or Jolanda. All of the $F_{1}$ plants of crosses with Taishokintoki were susceptible to ClYVV, whereas those produced by crossing with Jolanda showed resistance. These observations indicate that Evolutie and Imuna also contain desc.

\section{CIYVV-Br that overcomes the resistance of Jolanda.}

Of 10 inoculated CF-15 plants, 2 showed slightly higher ELISA values than healthy controls (Table 1). During prolonged growth of these two inoculated CF-15 plants in a greenhouse, they occasionally developed chlorotic spots on the upper leaves. A spontaneous mutant that infects Jolanda was recovered and designated ClYVV-Br. ClYVV-Br-infected Jolanda showed typical ClYVV symptoms, including chlorotic spots, leaf distortion, and stunting 7 to 10 dpi. Using ELISA, we confirmed that the viral accumulation in Jolanda was as high as that in Taishokintoki (data not shown).

We then cloned genomic fragments of ClYVV-Br and made a series of chimeric constructs between CIYVV/C3-S65T and

Table 4. Genetic analysis of resistance to CIYVV in crosses between Jolanda and Taisyokintoki

\begin{tabular}{|c|c|c|c|c|c|c|c|}
\hline \multirow[b]{2}{*}{ Generation } & \multirow{2}{*}{$\begin{array}{l}\text { Plant }^{\mathbf{a}} \\
\subsetneq \times \circlearrowleft\end{array}$} & \multicolumn{3}{|c|}{ No. of plants ${ }^{b}$} & \multirow[b]{2}{*}{ Expected ratio $^{c}$} & \multirow[b]{2}{*}{$\chi^{2}$} & \multirow{2}{*}{$\begin{array}{l}\text { Goodness of fit } \\
\qquad(\mathrm{Pa}=0.05)^{\mathrm{c}}\end{array}$} \\
\hline & & Total & Susceptible & Resistant & & & \\
\hline \multirow[t]{2}{*}{ Parent } & Taishokintoki (T) & $\ldots$ & $\ldots$ & $\ldots$ & $\ldots$ & $\ldots$ & $\ldots$ \\
\hline & Jolanda (J) & $\ldots$ & $\ldots$ & $\ldots$ & $\ldots$ & $\ldots$ & $\ldots$ \\
\hline \multirow[t]{2}{*}{$\mathrm{F} 1$} & $\mathrm{~T} \times \mathrm{J}(\mathrm{F} 1)$ & $\ldots$ & $\ldots$ & $\ldots$ & $\ldots$ & $\ldots$ & $\ldots$ \\
\hline & $\mathrm{J} \times \mathrm{T}(\mathrm{F} 1)$ & $\ldots$ & $\ldots$ & $\ldots$ & $\ldots$ & $\ldots$ & $\ldots$ \\
\hline \multirow[t]{2}{*}{$\mathrm{F} 2$} & $\mathrm{~T} \times \mathrm{J}(\mathrm{F} 2)$ & $\ldots$ & $\ldots$ & $\ldots$ & $3: 1$ & 1.28 & 0.3 to 0.2 \\
\hline & $\mathrm{J} \times \mathrm{T}(\mathrm{F} 2)$ & 43 & 30 & 13 & $3: 1$ & 0.62 & 0.9 to 0.8 \\
\hline Backcross & $\mathrm{J} \times[\mathrm{T} \times \mathrm{J}(\mathrm{F} 1)]$ & & & & $1: 1$ & 0.06 & 0.8 to 0.7 \\
\hline$F 3^{d}$ & $\mathrm{~T} \times \mathrm{J}(\mathrm{F} 3)$ & 64 & $\ldots$ & 64 & $\ldots$ & $\ldots$ & $\ldots$ \\
\hline
\end{tabular}

${ }^{\mathrm{a}}$ Progenies from crossing between Taishokintoki and Jolanda.

${ }^{b}$. Response to ClYVV infection was judged by the amount of green fluorescent protein seen 2 days postinoculation under epifluorescence microscopy.

c A single recessive resistance gene was expected.

${ }^{\mathrm{d}}$ F3 plants were derived from resistant F2 plants.

Table 5. Response to ClYVV infection in cultivars with the resistance genes to Bean common mosaic virus ${ }^{\mathrm{a}}$

\begin{tabular}{|c|c|c|c|c|c|}
\hline \multirow[b]{2}{*}{ Genotype groups } & \multirow[b]{2}{*}{ Cultivars } & \multicolumn{3}{|c|}{ Resistance genes } & \multirow[b]{2}{*}{ Response $^{b}$} \\
\hline & & $I$ & $b c-1-1$ & $b c-u$ & \\
\hline \multirow[t]{5}{*}{ A } & Jolanda & + & + & + & $\mathrm{R}$ \\
\hline & Canning King & + & + & + & $\mathrm{S}$ \\
\hline & Evolutie & + & + & + & $\mathrm{R}$ \\
\hline & Titan & + & + & + & $\mathrm{S}$ \\
\hline & Troketta & + & + & + & $\mathrm{S}$ \\
\hline \multirow[t]{4}{*}{ B } & Alabama 1 & + & $\ldots$ & + & $\mathrm{S}$ \\
\hline & Black Turtle Soup & + & $\ldots$ & + & $\mathrm{S}$ \\
\hline & Jamapa & + & $\ldots$ & + & $\mathrm{S}$ \\
\hline & Widusa & + & $\ldots$ & + & $\mathrm{S}$ \\
\hline \multirow[t]{3}{*}{$\mathrm{C}$} & Asta & $\ldots$ & + & + & S \\
\hline & Hylowska Bila & $\ldots$ & + & + & $\mathrm{S}$ \\
\hline & Imuna & $\ldots$ & + & + & $\mathrm{R}$ \\
\hline
\end{tabular}

${ }^{a}$ Cultivars with resistance gene to Bean common mosaic virus were collected and subjected to ClYVV/C3-S65T inoculation. Groups A, B, and C were classified according to their genotypes.

${ }^{\mathrm{b}} \mathrm{R}=$ resistance; $\mathrm{S}$ = susceptible. 
ClYVV-Br (Fig. 6A). The chimeras then were bombarded onto the leaves of Taishokintoki and Jolanda, and their infection was monitored by GFP fluorescence. The infectivity of the clones is shown in Figure 6A. We mapped the region responsible for breaking the resistance to the region covered by a SacI-SalI fragment. Although there are no amino acid differences in CI and $6 \mathrm{~K} 2$ in the two parental viruses, three amino acid substitutions were found in the VPg region (Fig. 6B), suggesting that VPg is the avirulence determinant.

\section{DISCUSSION}

The resistance to ClYVV appeared to operate at the singlecell level, because we found no GFP fluorescence in leaves inoculated with ClYVV/C3-S65T. This observation perhaps was due to either inhibition of viral multiplication in a single cell or HR-like cell death that occurred very rapidly. If the virus can multiply in a cell, but cannot move from cell to cell, we should see GFP fluorescence, at least in the virus-introduced cells, as demonstrated for the other viruses (Carrington et al. 1998; Hirashima and Watanabe 2001). By contrast, if the virus-introduced cells are killed by rapid cell death, we should observe some of the autofluorescence often associated with HR (Fig. $5 \mathrm{E})$. Cooley and associates (2000) reported that small local lesions were observed in transgenic plants expressing a resistance gene that causes micro-HR; therefore, the resistance gene actually killed the virus-infected cells. To test the possibility of such micro-HR, we separated the CIYVV genome and the GFP gene into two plasmids and conducted simultaneous introduc- tion into plant cells (Fig. 4). We found marked enhancement of GFP fluorescence in the GFP-introduced cells over time, despite co-introduction of ClYVV into the cells, indicating that those cells were still viable. Therefore, it is unlikely that the virus-introduced cells were killed by the resistance mechanism at the single-cell level. Thus, we believe that the absence of GFP fluorescence in Jolanda is due to inhibition of viral replication of ClYVV/C3-S65T in single cells.

In this study, we demonstrated that GFP-tagged ClYVV can be used to monitor virus accumulation and movement in real time. In contrast to the results of German-Retana and associates (2000), the GFP-tag did not affect the resistance of Jolanda inoculated with CIYVV/C3-S65T. Furthermore, the GFP gene has been stably maintained in the viral genome for at least five passages in common bean, as in broad bean (Masuta et al. 2000); to date no GFP deletion mutants have been found. TEV also has been successfully tagged with GFP (Carrington et al. 1998; Schaad et al. 1997a), although GUS-tagged viruses are more commonly used (Hinrichs-Berger et al. 2000; Johansen et al. 2001; Schaad et al. 1997b). A GFP-tagged virus has a great advantage; it enables us to continuously monitor viral replication and movement in living cells during viral infection. Here, we demonstrated our successful application of GFP-tagged ClYVV to the analysis of viral resistance in Jolanda.

Genetic analyses indicate that Jolanda contains a single recessive CIYVV resistance allele. One interpretation of the recessive resistance is that the resistant plant lacks a factor necessary for viral infection (Fraser 1992). Alternatively, it is possible that the recessive resistance is due to the lack of a nega-
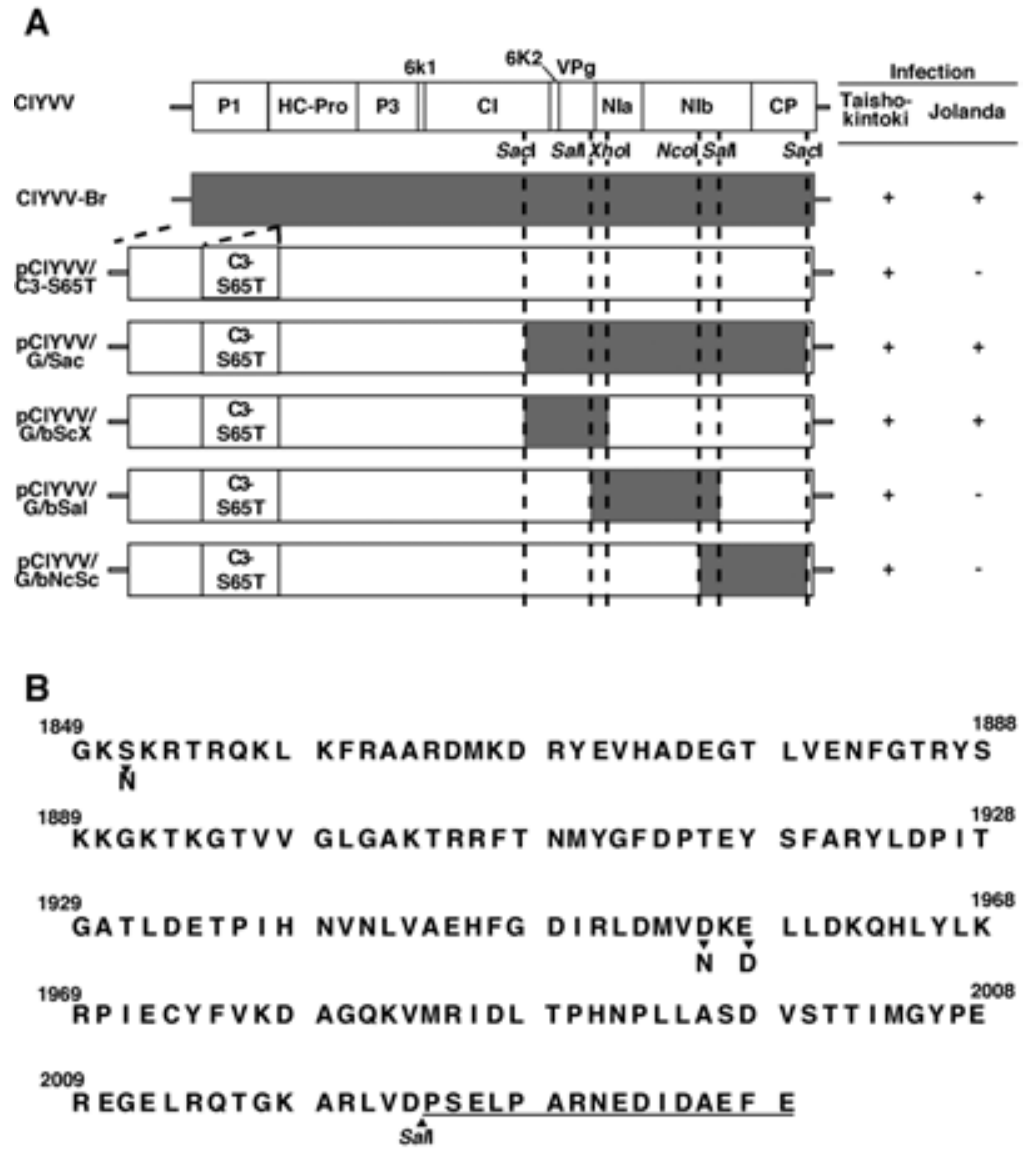

Fig. 6. Schematic representation of chimeric clones between wild and spontaneous mutant ClYVV-Br. A, Chimeric clones were used to construct SacI, SalI, NcoI, and XhoI sites. Each construct was bombarded onto the leaves of susceptible Taishokintoki and resistant Jolanda. (+) and (-) indicate the incidence of green fluorescent protein fluorescence 3 days postinoculation. B, The amino acid sequence of viral genome-linked protein of ClYVV-Br. Three amino acid substations were identified using four independent sequences. The underlined amino acids were downstream from the SalI site in viral genome-linked protein. 
tive regulator in a general resistance mechanism (Freialdenhoven et al. 1996). However, Arabidopsis mutants showing immunity to several potyviruses recently have been isolated, and some mutations of eIF(iso) $4 \mathrm{E}$ were found to be involved in the resistance (Duprat et al. 2002; Lellis et al. 2002). As far as the nature of the immunity is concerned, the Jolanda resistance is similar to that found in those Arabidopsis mutants. In addition, Ruffel and associates (2002) recently found a mutant form of eIF4E in pepper that corresponds to the gene $p v r 2$ for natural recessive resistance to PVY. Based on this knowledge, we speculate that desc may be eIF4E or its isoform.

Using chimeric viruses, we also showed that the VPg was associated with the resistance-breaking of a spontaneous mutant ClYVV-Br. Potyvirus VPg actually participates in several steps in the viral infection cycle and has been identified as an avirulence determinant in some potyviruses (Hjulsager et al. 2002; Keller et al. 1998; Masuta et al. 1999; Nicolas et al. 1997; Ramajaki and Valkonen 2002; Schaad et al. 1997b). We currently are analyzing the possible interaction between $\mathrm{VPg}$ and eIF4E (or its isoform) in the immunity-type resistance of Jolanda to ClYVV.

\section{MATERIALS AND METHODS}

\section{Plant and virus materials.}

Inocula were prepared as follows. First, pClYVV (Takahashi et al. 1997) or pClYVV/C3-S65T was mechanically inoculated onto broad bean plants (Vicia faba, cv. Wasesoramame). Approximately 1 week later, symptomatic leaves were used for inoculation onto common bean (Phaseolus vulgaris). The cultivars listed in Table 1 were gifts from the Hokkaido Central Agricultural Experiment Station, and those listed in Table 5 were gifts from the Hokkaido Tokachi Agricultural Experiment Station.

\section{Evaluation of CIYVV resistance.}

The level of resistance was determined from the incidence of disease symptoms and the results of an ELISA. Plants were grown in a greenhouse. Inocula in a solution of $0.1 \mathrm{M}$ Tris- $\mathrm{HCl}$ $(\mathrm{pH} 7.0)$ and $1 \%$ 2-mercaptoethanol were ground with a mortar and pestle. Primary leaves of 7- to 10-day-old plants were used for inoculation. Of each cultivar, 5 to 10 plants were provided for inoculation. Leaves were dusted with carborundum and inoculated mechanically. At 10 dpi, the upper leaves were subjected to ELISA with anti-ClYVV antibody according to the procedure described previously (Masuta et al. 2000). When an ELISA value was more than twice as high as that of mockinoculated controls, we rated it as "positive". The antibody was prepared by ammonium sulfate precipitation from antiserum against the virus (Uyeda et al. 1975).

As a bioassay to verify the ELISA results, Taishokintoki was used to detect virus from Jolanda that had been inoculated with ClYVV 10 days previously.

\section{Construction of pCIYVV/C3-S65T, pCIYVV-35S:G:N, and pE2113-ECFP.}

We initially used cycle3 GFP to create a recombinant CIYVV expressing GFP (Masuta et al. 2000) because the cycle3 mutant was the brightest soluble mutant available at that time (Crameri et al. 1996). pClYVV/C3-S65T was constructed according to the procedure of Masuta and associates (2000). In this study, we replaced cycle 3 with a modified cycle 3 (smRSGFP), which has four amino acid substitutions and induces much brighter fluorescence than cycle3. The codon usage in smRS-GFP has been modified for efficient expression in higher plants (Davis and Vierstra 1998). For pCl-35:G:N, the primer pair no. 855 (5'-GGGAGATCTGGGGTACCAAGCTTGAACATGGTGGA GC-3') and no. 856 (5'-GGGAGATCTC-
CACTAGTGAATTCCCGATCTAGTAA-3') was used to create a $B g l I I$ site (underlined) at the ends of a GFP expression cassette with the Cauliflower mosaic virus $35 \mathrm{~S}$ promoter. The $B g l$ II-digested polymerase chain reaction (PCR) product was inserted in the BamHI site of pClYVV, which is just downstream from the virus $3^{\prime}$ end. The expression of functional GFP and the viral infection from the recombinant plasmid was confirmed by monitoring fluorescence and the development of symptoms on broad bean, respectively. To identify the cells to which DNA was delivered, we used an additional reporter gene, the ECFP gene. The fluorescence of ECFP is darker than that of GFP; therefore, we increased expression of ECFP by cloning it downstream from a modified 35S promoter (Mitsuhara et al. 1996).

\section{Experiments using detached leaves.}

After detached leaves had been inoculated with GFP-tagged virus or bombarded with DNA using a PDS-1000/He Particle Delivery System (Bio-Rad, Hercules, CA, U.S.A.), GFP fluorescence was monitored. Resistance was at the single-cell level in the inoculated leaves; therefore, we did not need to analyze entire plants, but only inoculated leaves. In addition, our method of monitoring viral infection in detached leaves has the advantage of requiring only 3 days to assess viral infection.

\section{Biolistic assay.}

Tungsten particles were prepared and coated with DNA, as described previously (Gal-On et al. 1997) with the following modifications. Briefly, 0.18-mg aliquots of tungsten particles (Bio-Rad) were mixed with $0.5 \mu \mathrm{g}$ (to introduce psmRSGFP or a 4-to-1 mixture of pClYVV/C3-S65T to pE2113-ECFP) or 1.5 $\mu \mathrm{g}$ (to introduce pClYVV-35:G:N) of DNA in distilled water and calcium nitrate $(1.25 \mathrm{M}, \mathrm{pH} 10.5)$, followed by ethanol precipitation. Then, the precipitate was suspended in $60 \mu \mathrm{l}$ of ethanol. Bombardment was carried out with a PDS-1000/He Particle Delivery System (Bio-Rad), using leaves from 1week-old plants. After bombardment, the leaves were incubated at $24^{\circ} \mathrm{C}$ in the dark and subjected to GFP imaging.

\section{GFP and CFP imaging.}

GFP fluorescence was examined using an epifluorescence microscope (SZX-12; OLYMPUS, Tokyo) equipped with a GFP cube (SZX-MGFPA; OLYMPUS), or a confocal laser microscopy system ( $\mu$ Radiance2000; Bio-Rad) with a filter block (Nikon, Tokyo) containing a 450- to 490-nm excitation filter, a 510-nm dichroic mirror, and a 520-nm barrier filter. SZX-12 micrographs were obtained with 400 ASA Fujichrome film.

To observe CFP fluorescence, an SZX-12 equipped with a CFP cube (SZX-MCFPA; OLYMPUS) was used.

\section{Segregation analysis in crosses.}

$\mathrm{F}_{1}$ plants were obtained by crossing Jolanda and Taishokintoki. Detached leaves of $104 \mathrm{~F}_{2}$ plants were inoculated with ClYVV/C3-S65T, then incubated at $24^{\circ} \mathrm{C}$ in the dark. Infection with ClYVV/C3-S65T was determined by monitoring GFP fluorescence 2 dpi. Some of the $F_{1}$ plants were backcrossed with Jolanda.

\section{Examination of cultivars containing $I, b c-1$, and $b c-u$.}

Jolanda possesses the BCMV resistance genes $I, b c-1-1$, and $b c-u$. To determine the effects of these genes on CIYVV resistance, we collected the cultivars listed in Table 5 containing all three or various pairwise combinations of the three genes. Detached leaves of all cultivars were inoculated with ClYVV/C3S65T, using five plants for each cultivar. Susceptibility to ClYVV was confirmed by monitoring GFP fluorescence and symptom development. 


\section{Construction of chimeric clones \\ between CIYVV and CIYVV-Br.}

Total RNA was extracted from the upper leaves of CF-15 infected systemically by ClYVV-Br and reverse transcription PCR was conducted with primer no. 297 (5'-CCTTTTTTTTTT CTCGCTCTATAAAGATCAG-3'). The C-terminal half of the genomic region was amplified by PCR using the first strand cDNA and the primer pair consisting of no. 297 and $448\left(5^{\prime}-\right.$ GTTGTTTTAAACAAAATGGCTATAC- $3^{\prime}$ ). The amplified region then was cloned into the $\mathrm{SacI}$ site of pBluescript-SK(-) (TOYOBO, Osaka, Japan) and sequenced. Chimeric clones between ClYVV and ClYVV-Br (pClYVV/G/bSac, $\mathrm{pClYVV} / \mathrm{G} / \mathrm{bScX}, \mathrm{pClYVV} / \mathrm{G} / \mathrm{bSal}$, and $\mathrm{pClYVV} / \mathrm{G} / \mathrm{bNcSc}$ ) were constructed using the restriction sites indicated in Figure 6A. They were bombarded into Taishokintoki and Jolanda to examine infectivity.

\section{ACKNOWLEDGMENTS}

This work was supported in part by "Molecular Mechanisms of PlantPathogenic Microbe Interaction", a grant-in-aid for scientific research on priority areas (A) from the Ministry of Education, Culture, Sports, Science, and Technology of Japan (no. 08680733) to I. Uyeda. We thank Y. Watanabe (University of Tokyo) for critical reading of the manuscript and kindly providing psmRSGFP, I. Mitsuhara and Y. Ohashi (National Institute of Agrobiological Science) for providing pE2113-GUS, M. Isogai (Iwate University) for providing pECFP-1, the Hokkaido Tokachi Agricultural Experiment Station and Hokkaido Central Agricultural Experiment Station for their kind gifts of common bean seed, and H. Sato (Hokkaido Central Agricultural Experiment Station) and H. Sekiguchi (Hokkaido Green Bio Institute) for their help with performing the plant crosses.

\section{LITERATURE CITED}

Carrington, J. C., Jensen, P. E., and Schaad, M. C. 1998. Genetic evidence for an essential role for potyvirus CI protein in cell-to-cell movement. Plant J. 14:393-400

Cooley, M. A., Pathirana, S., Wu, H.-J., Kachroo, P., and Klessing, D. F 2000. Members of the Arabidopsis HRT/RPP8 family of resistance genes confer resistance to both viral and oomycete pathogens. Plant Cell 12:663-676.

Crameri, A., Whitehorn, E. A., Tate, E., and Stemmer, W. P. 1996. Improved green fluorescent protein by molecular evolution using DNA shuffling. Nat. Biotechnol. 14:315-319.

Davis, S. J., and Vierstra, R. D. 1998. Soluble, highly fluorescent variants of green fluorescent protein (GFP) for use in higher plants. Plant Mol. Biol. 36:521-528.

Drijfhout, E. 1978. Genetic interaction between Phaseolus vulgaris L. and bean common mosaic virus with implications for strain identification and breeding for resistance. Agric. Res. Rep. 872, Center Agriculture Publishing and Documentation, Wageningen, the Netherlands.

Duprat, A., Caranta, C., Revers, F., Menand, B., Browning, K. S., and Robaglia, C. 2002. The Arabidopsis eukaryotic initiation factor (iso) $4 \mathrm{E}$ is dispensable for plant growth but required for susceptibility to potyviruses. Plant J. 32:927-934.

Fraser, R. S. S. 1992. The genetics of plant-virus interactions: implications for plant breeding. Euphytica 63:175-185.

Freialdenhoven, A., Peterhänsel, C., Kurth, J., Kreuzaler, F., and SchulzeLefert, P. 1996. Identification of genes required for the function of non-race-specific mlo resistance to powdery mildew in barley. Plant Cell 8:5-14

Gal-On, A., Meiri, E., Elman, C., Gray, D. J., and Gaba, V. 1997. Simple hand-held devices for the efficient infection of plants with viralencoding constructs by particle bombardment. J. Virol. Methods 64:103-110.

German-Retana, S., Candresse, T., Delbos, R., and Gall, O. L. 2000. Effects of green fluorescent protein or beta-Glucuronidase tagging on the accumulation and pathogenicity of a resistance breaking lettuce mosaic virus isolate in susceptible and resistant lettuce cultivars. Mol. Plant-Microbe Interact. 13:316-324.

Hinrichs-Berger, J., Junghans, H., and Buchenauer, H. 2000. Early selection for extreme resistance to potato virus $\mathrm{Y}$ and tobacco etch virus in potato using a $\beta$-glucuronidase-tagged virus. Plant Breed. 119:319-323.

Hirashima, K., and Watanabe, Y. 2001. Tobamovirus replicase coding region is involved in cell-to-cell movement. J. Virol. 75:8831-8836.

Hjulsager, C. K., Lund, O. S., and Johansen, I. E. 2002. A new pathotype of pea seed-borne mosaic virus explained by properties of the P3-6K1 and viral genome-linked (VPg) coding regions. Mol. Plant-Microbe Interact. 15:169-171.

Johansen, I. E., Lund, O. S., Hjulsager, C. K., and Laursen, J. 2001. Recessive resistance in Pisum sativum and potyvirus pathotype resolved in a gene-for-cistron correspondence between host and virus. J. Virol. 75:6609-14.

Keller, K. E., Johansen I. E., Martin R. R., and Hampton R. O. 1998. Potyvirus genome-linked protein VPg. determines pea seed-borne mosaic virus pathotype-specific virulence in Pisum sativum. Mol. Plant-Microbe Interact. 11:124-30.

Lellis, A. D., Kasschau, K. D., Whitham, S. A., and Carrington, J. C. 2002. Loss-of-susceptibility mutants of Arabidopsis thaliana reveal an essential role for eIF(iso)4E during potyvirus infection. Curr. Biol. 12:1046-1051.

Masuta, C., Nishimura, M., Morishita, H., and Hataya, T. 1999. A single amino acid change in viral genome-associated protein of potato virus $Y$ correlates with resistance breaking in 'Virgin A mutant' tobacco. Phytopathology 89:118-123.

Masuta, C., Yamana, T., Tacahashi, Y., Uyeda, I., Sato, M., Ueda, S., and Matsumura T. 2000. Development of Clover yellow vein virus as an efficient, stable gene-expression system for legume species. Plant J. 23:539-46.

Mitsuhara, I., Ugaki, M., Hirochika, H., Ohshima, M., Murakami, T., Gotoh, Y., Katayose, Y., Nakamura, S., Honkura, R., Nishimiya, S. Ueno, K., Mochizuki, A., Tanimoto, H., Tsugawa, H., Otsuki, Y., and Ohashi Y. 1996. Efficient promoter cassettes for enhanced expression of foreign genes in dicotyledonous and monocotyledonous plants. Plant Cell Physiol. 37:49-59.

Nicolas, O., Dunnington, S. W., Gotow, L. F., Pirone, T. P., and Hellmann, G. M. 1997. Variations in the VPg protein allow a potyvirus to overcome va gene resistance in tobacco. Virology 237:452-459.

Nicolas, O., Pirone, T. P., and Hellmann, G. M. 1996. Construction and analysis of infectious transcripts from a resistance-breaking strain of tobacco vein mottling potyvirus. Arch. Virol. 141:1535-1552.

Noguchi, S., Tajima, T., Yamamoto, Y., Ohno, T., and Kubo T. 1999. Deletion of a large genomic segment in tobacco varieties that are resistant to potato virus $Y$ (PVY). Mol. Gen. Genet. 262:822-829.

Provvidenti, R., and Hampton, R. O. 1992. Sources of resistance to viruses in the Potyviridae. Arch. Virol. Suppl. 5:189-211.

Ramajaki, M. L., and Valkonen, J. P. T. 2002. Viral genome-linked protein $(\mathrm{VPg})$ controls accumulation and phloem-loading of a potyvirus in inoculated potato leaves. Mol. Plant-Microbe Interact. 15:138-149.

Ruffel, S., Dussault, H., Palloix, A., Moury, B., Bendahmane, A., Robaglia, C., and Caranta, C. 2002. A natural recessive resistance gene against potato virus $\mathrm{Y}$ in pepper corresponds to the eukaryotic initiation factor 4E (eIF4E). Plant J. 32:1067-1075.

Schaad, M. C., Jensen, P. E., and Carrington, J. C. 1997a. Formation of plant RNA virus replication complex on membranes: role of an endoplasmic reticulum-targeted viral protein. EMBO J. 16:40494059.

Schaad, M. C., Lellis, A. D., and Carrington, J. C. 1997b. VPg of tobacco etch virus is a host genotype-specific determinant for long-distance movement. J. Virol. 71:8624-8631.

Shukla, D. D., Ward, C. W., and Brunt, A. A. 1994. The Potyviridae. CAB International, Wallingford, U.K.

Takahashi, Y., Takahashi, T., and Uyeda, I. 1997. An infectious cDNA clone to Clover yellow vein potyvirus genome is highly infectious. Virus Genes 14:235-243.

Uyeda, I., Kojima, M., and Murayama, D. 1975. Purification and serology of bean yellow mosaic virus . Ann. Phytopathol. Soc. Jpn. 41:192-203.

Uyeda, I., Takahashi, T., and Shikata, E. 1991. Relatedness of the nucleotide sequence of the 3'-terminal region of clover yellow vein potyvirus RNA to bean yellow mosaic potyvirus RNA. Intervirology $32: 234-245$. 